\title{
Correction to: Exploring the relationship between mobility and COVID- 19 infection rates for the second peak in the United States using phase-wise association
}

Raju Gottumukkala1,2*, Satya Katragadda', Ravi Teja Bhupatiraju', Azmyin Md. Kamal', Vijay Raghavan', Henry Chu', Ramesh Kolluru ${ }^{1}$ and Ziad Ashkar ${ }^{1}$

Correction to: BMC Public Health. 21, 1669 (2021)

http://orcid.org/10.1186/s12889-021-11657-0

It was highlighted that in the original article [1] the two given names of author Azmyin Md. Kamal were erroneously interchanged. The original article has been updated.

Published online: 26 October 2021

\section{Reference}

1. Gottumukkala R, et al. Exploring the relationship between mobility and COVID- 19 infection rates for the second peak in the United States using phase-wise association. BMC Public Health. 2021;21:1669. https://doi.org/1 0.1186/s12889-021-11657-0.

The original article can be found online at https://doi.org/10.1186/s12889021-11657-0.

* Correspondence: gnraju@ieee.org

1 Informatics Research Institute, University of Louisiana at Lafayette, Lafayette, USA

${ }^{2}$ Mechanical Engineering Department, University of Louisiana at Lafayette,

Lafayette, USA

C C The Author(s). 2021 Open Access This article is licensed under a Creative Commons Attribution 4.0 International License, which permits use, sharing, adaptation, distribution and reproduction in any medium or format, as long as you give appropriate credit to the original author(s) and the source, provide a link to the Creative Commons licence, and indicate if changes were made. The images or other third party material in this article are included in the article's Creative Commons licence, unless indicated otherwise in a credit line to the material. If material is not included in the article's Creative Commons licence and your intended use is not permitted by statutory regulation or exceeds the permitted use, you will need to obtain permission directly from the copyright holder. To view a copy of this licence, visit http://creativecommons.org/licenses/by/4.0/. The Creative Commons Public Domain Dedication waiver (http://creativecommons.org/publicdomain/zero/1.0/) applies to the data made available in this article, unless otherwise stated in a credit line to the data. 